IZA DP No. 10297

Privatisation in Developing Countries:

What Are the Lessons of Recent Experience?

Saul Estrin

Adeline Pelletier

October 2016 


\title{
Privatisation in Developing Countries: What Are the Lessons of Recent Experience?
}

\author{
Saul Estrin \\ London School of Economics \\ and IZA \\ Adeline Pelletier \\ Goldsmiths College, University of London \\ and CEP, LSE
}

Discussion Paper No. 10297
October 2016

\author{
IZA \\ P.O. Box 7240 \\ 53072 Bonn \\ Germany \\ Phone: +49-228-3894-0 \\ Fax: +49-228-3894-180 \\ E-mail: iza@iza.org
}

Any opinions expressed here are those of the author(s) and not those of IZA. Research published in this series may include views on policy, but the institute itself takes no institutional policy positions. The IZA research network is committed to the IZA Guiding Principles of Research Integrity.

The Institute for the Study of Labor (IZA) in Bonn is a local and virtual international research center and a place of communication between science, politics and business. IZA is an independent nonprofit organization supported by Deutsche Post Foundation. The center is associated with the University of Bonn and offers a stimulating research environment through its international network, workshops and conferences, data service, project support, research visits and doctoral program. IZA engages in (i) original and internationally competitive research in all fields of labor economics, (ii) development of policy concepts, and (iii) dissemination of research results and concepts to the interested public.

IZA Discussion Papers often represent preliminary work and are circulated to encourage discussion. Citation of such a paper should account for its provisional character. A revised version may be available directly from the author. 


\section{ABSTRACT \\ Privatisation in Developing Countries: What Are the Lessons of Recent Experience? ${ }^{1}$}

This paper reviews recent empirical evidence on privatisation in developing countries. Particular emphasis is placed on new areas of research such as the distributional impacts of privatisation. Overall, the literature now reflects a more cautious and nuanced evaluation of privatisation. Thus it is found that private ownership alone does not automatically generate economic and employment gains in developing economies; pre-conditions (especially the regulatory infrastructure) and the process of privatisation are important to attain a positive impact. Such factors include well-designed and sequenced reforms; the implementation of complementary policies; the creation of regulatory capacity; attention to poverty and social impacts; and strong public communication; a list which is often challenging in developing countries. However, the studies do identify scope for efficiency-enhancing privatisation which also promotes equity in developing countries.

JEL Classification: L1, L51, O10

Keywords: impact of privatisation, economic reforms, developing economies, regulation, distribution of income

Corresponding author:

Saul Estrin

London School of Economics

Houghton St

London WC2A 2AE

United Kingdom

E-mail: s.estrin@Ise.ac.uk

\footnotetext{
${ }^{1}$ This work was supported by the U.K. Department for International Development and the Overseas Development Institute. The authors would like to acknowledge help and comments from Tim Green, Deborah McGurk, Anne McKinnon, Bill Megginson, John Nellis, Alberto Lemma, Jon Stern and Jan Svejnar. Any remaining errors are their own responsibility.
} 


\section{Introduction}

There is a large literature about the economic effects of privatisation. However, being mainly written one or two decades ago, this usually does not take account of issues which have come to the fore more recently, nor of more recent developments in the evidence about privatisation itself, much of it from developing economies. It is these deficiencies that have led us to write this paper, which focuses on the evidence about the outcomes of recent privatisation, not only in terms of firms' efficiency but also in terms of the wider distributional aspects, which are of special relevance for developing countries. In addition, we are particularly attentive to the process of privatisation in developing countries, notably with respect to the regulatory apparatus enabling successful privatisation experiences.

When governments have divested state-owned enterprises in developed economies, their goals have traditionally been to encourage economic efficiency by improving firm performance; to decrease government intervention and increase its revenue; and to introduce competition in monopolised sectors. Much of the early evidence about the economic impact of privatisation in these areas, but especially concerning economic performance, was based on data from developed countries and transition countries. These findings have been brought together in two previous surveys, by Megginson and Netter (2001) and Estrin et al. (2009). The former assesses the findings of empirical research on the effects of privatisation; it surveys the literature up to 2000, mainly from developed and middle income countries; attempts to frame and answer the key questions this stream of research addressed; and describes the lessons for the promise and perils of selling state-owned assets. The latter focuses on transition economies, and evaluates what has been learned about the effects of privatisation 1989-2006 in the post-communist economies and China. ${ }^{2}$ The recent waves of privatisations that have occurred in a variety of sectors in developing countries therefore

\footnotetext{
${ }^{2}$ Kikeri and Nellis (2004) have also conducted a wide-ranging assessment of privatisation.
} 
warrant a new examination of the impact of privatisation in the context of the development process.

Before turning to the evidence it is worth noting that the tone of the privatisation debate regarding developing countries has shifted in the international financial institutions, to acknowledge the difficulties of implementation and some privatisation failures in the 1980s and 1990s (Jomo, 2008). As a result, more emphasis in policy making is now being placed on creating the preconditions for successful privatisation. Thus, it is proposed that governments should first provide better regulatory and institutional framework, with a well-functioning capital market and the protection of consumer and employee rights, and then that reforms should be tailor-made for the circumstances, with strategies for privatisation being adapted to local conditions.

In terms of privatisation objectives, improving the efficiency of public enterprises remains a major goal in developing countries. In addition, with mounting external debt repayment obligations in many developing economies, one of the apparently least painful cuts that can be made in the short-run is to public sector investment. Subsidies to state owned enterprises (SOEs), whether a result of recurrent losses, or to finance investment, crowd out other expenditures in the budget. This creates a double gain from privatisation as there are a oneoff capital receipts when companies are sold and a long-term gain from reduced subsidies and hopefully eventually from increased tax revenues if loss-making subsidised public enterprises are transformed into profit making private ones which pay tax. If the public sector fails to control the costs of SOEs, especially employment costs, privatisation can be hard to avoid because the problems cannot be tackled within the public sector.

This article reviews the evidence on privatisation, with emphasis on recent trends in developing countries. The first section presents some stylized facts. The second examines the 
effects of privatisation in terms of firms' efficiency and performance. In section three, we go on to examine the distributional impacts of privatisation. Policy recommendations are then developed.

\section{Privatisation trends: stylized facts}

Privatisation trends since the late 1980s. The early literature focused on developed economies because Western Europe was the leader in privatisation (measured by revenues) from the 1970s to the new millennium, representing roughly a third of privatisation proceeds over the period 1977 to 2002 (Roland, 2008). Even so, many of these deals only concerned minority stakes of state-owned firms and governments have actually retained sizable residual shares in former SOEs (Bortolotti and Milella, 2008). Spectacular numbers of privatisations also took place during the transition process in Central and Eastern Europe, with proceeds totalling US\$240bns over the period 1988-2008 in addition to widespread free or subsidised share allocation to the general population (Estrin et al, 2009). The proceeds of privatisation have been more limited in Africa, the Middle East and South Asia, with total proceeds below US\$50bns for each of these regions ${ }^{3}$ (See Figure 1, with the latest data from the World Bank). However, they are on par or above Europe once they are expressed as a percentage of GDP.

In the rest of Asia, the picture is rather different. While South Asia has had a limited privatisation experience (India in particular), this was not the case in East Asia, with total privatisation proceeds of US\$230bns (30\% of total world proceeds) over the 1988-2008 period. China, in particular, stands out. Over a 25-year period, the Chinese government has

\footnotetext{
${ }^{3}$ Each of these three regions representing between 3\%-5\% of total world privatisation proceeds over the 19882008 period.
} 
encouraged innovative forms of industrial ownership, especially at the subnational level, that combine elements of collective and private property. New private entry and foreign direct investment have also been encouraged. As a result, by the end of the 1990s, the non-state sector accounted for over 60\% of GDP and state enterprises' share in industrial output had declined from 78\% in 1978 to 28\% in 1999 (Kikeri and Nellis, 2004).

Finally, in Latin America and especially in Chile, large-scale privatisation programs have been launched, especially in the infrastructure sector, starting in 1974 in Chile and culminating in the 1990s. Over the 1988-2008 period, the total privatisation proceeds in Latin America amounted to US\$220bns (28\% of total world proceeds).

Figure 1: Value of privatisation transactions in developing countries by region, $1988-08$

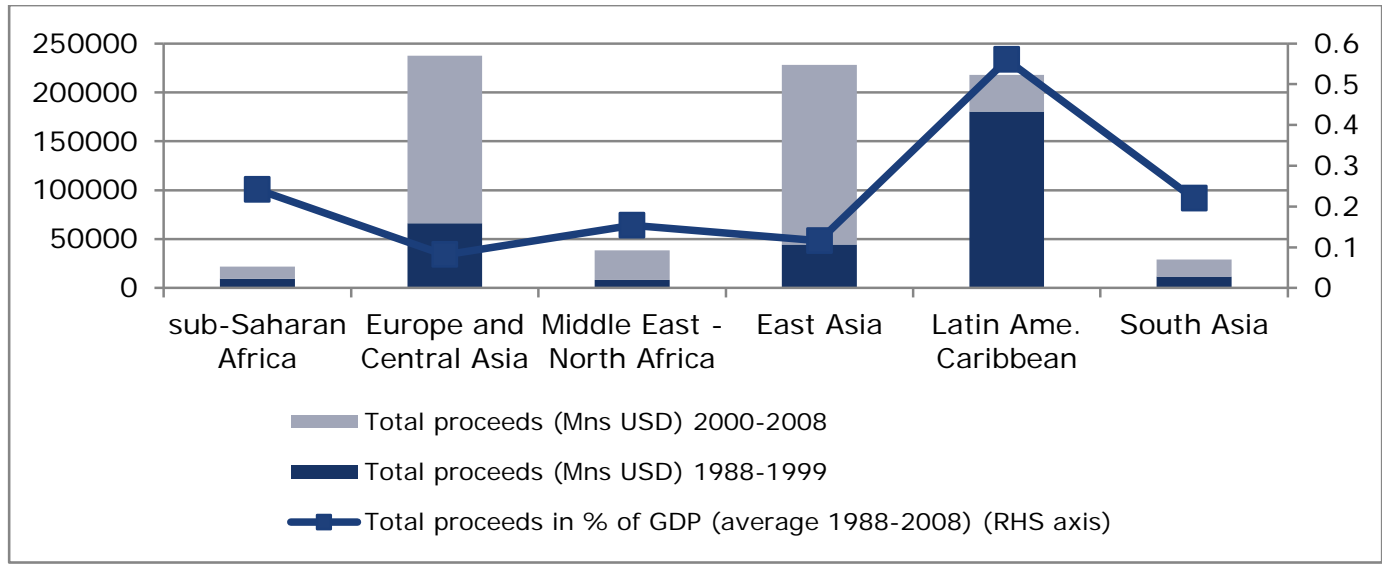

Source: World Bank, Privatisation database. Note: no data available in the Privatisation Database after 2008.

One needs to be cautious, however, when interpreting these figures. Indeed, examining these proceeds as a percentage of GDP, the picture is more nuanced and the differences between the privatisation experience of Africa, Asia and Europe become less striking, though proceeds are higher in Latin America privatisation, representing on average 0.5\% of GDP over the period (see Figure 1). 
Privatisation trends since 2008. The last five years have been marked by the predominance of China in worldwide privatisation, while the EU's share has been below its long-term average of $45 \%$ of total world's proceeds, running at only a third of worldwide totals on average.

According to the Privatisation Barometer (PB) Report 2013-2014, the global privatisation total proceeds exceeded US\$1.1 trillion from January 2009 to November 2014, including US\$544 billion divested assets between January 2012 and November 2014. In addition, the 20-month period beginning in January 2014 witnessed privatisations totalling \$431.4 billion (PB report 2015). This is far more than any comparable period since the beginning of the privatisation programs in the U.K. in the late 1970s (see Figure 2), though as noted below, a significant part of this was driven by the unwinding of positions taken in banks by governments during the financial crisis.

\section{Figure 2: Worldwide privatisation revenues 1988-2015 (USD bn)}

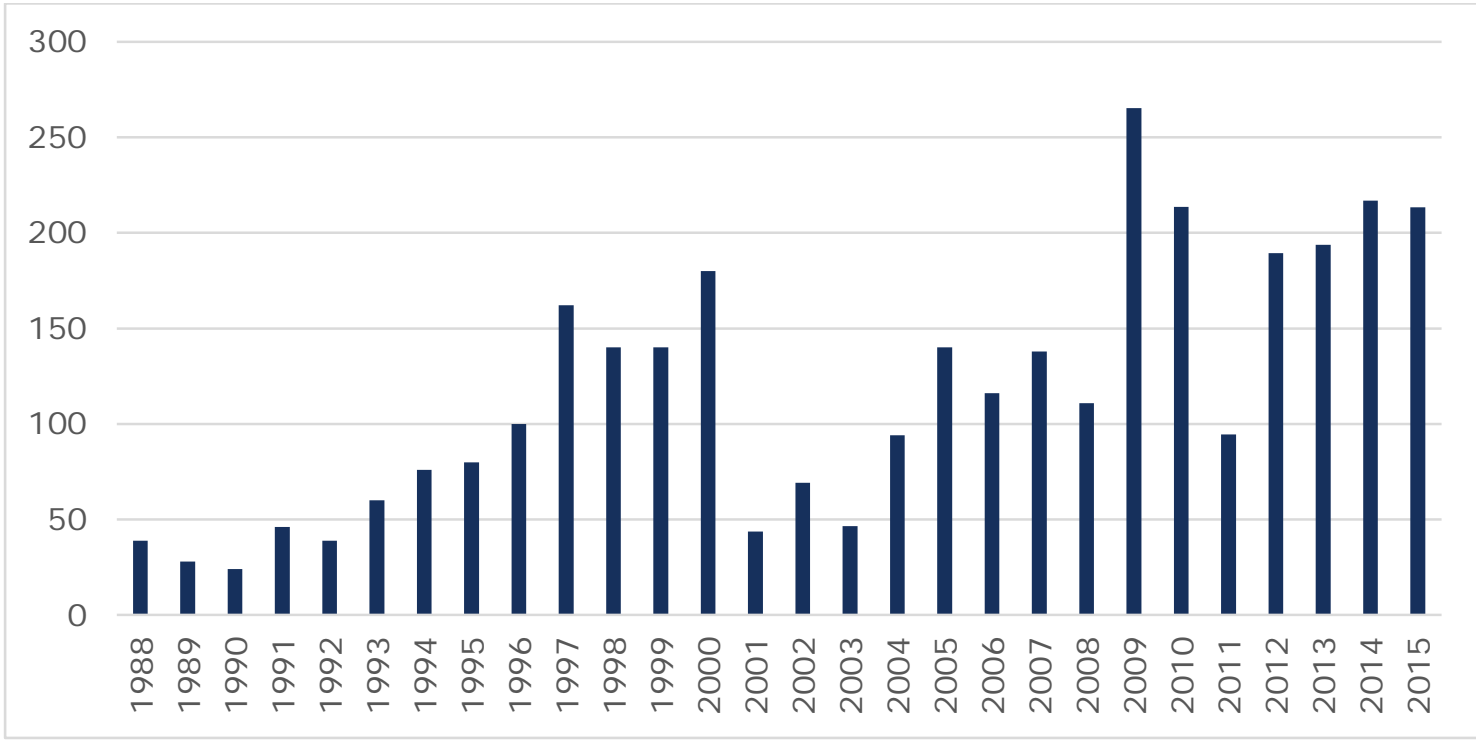

Note: 2015 is an estimate as of 30/08/2015. Source: Privatisation Barometer website.

As noted, China has consistently been one of the top privatisers over the last five years, being the second largest privatiser in 2009 and the first in 2013, 2014 and the 8-month period 
January-August 2015. Aggregate privatisation deals in China totalled more than US\$40 billion in both 2013 and 2014 and a spectacular $\$ 133.3$ billion in the first eight months of 2015 through 247 sales.

The bulk of China's privatisation proceeds came from the public and private placement offering of primary shares by SOEs (PB report, 2015). However the state's equity ownership stake was generally only reduced indirectly by increasing the total number of shares outstanding (PB report, 2015). In fact, Hsieh and Song (2015) have shown that almost half of the state-owned firms in 2007 and nearly 60 percent of them in 2012 were legally registered as private firms. The term used in China for this ownership change is that the large stateowned firms are "corporatized" rather than privatised. The typical form this "corporatization" form takes is that of a minority share traded in the stock market and merged into a large stateowned conglomerate, the controlling shareholder (Hsieh and Song, 2015).

The next leading country in terms of privatization proceeds after China is the U.K., but it is far behind, with total proceeds of US\$17.2 billion in 2014 (against US\$7.8bns in 2009).

In the EU as a whole, with countries addressing their government deficits post-2008, privatisation proceeds rose to a five-year peak in 2013, to $\$ 68.0$ billion and a nine-year peak of $\$ 77.6$ billion in 2014, while the annualized value of privatisations during 2015 - based on the first 8 months- reached $\$ 63.3$ billion. This represents more than a third of the global annual totals in 2014, but it is only 20.0\% of worldwide totals in the first 8 months of 2015 and lower than the long-run average EU share of about 44.6\% (PB report, 2015). This relative decline of EU privatisation proceeds is also reflected in the fact that China alone raised almost as much as did all EU countries combined during 2015 (\$68.0 billion versus $\$ 77.6$ billion for China) (PB report, 2015). 
Table 1: Ranking of top 5 emerging/developing countries by Total Privatisation Revenues, 2013-2015

\begin{tabular}{|c|c|c|c|c|c|c|c|c|}
\hline $\begin{array}{l}2013 \\
\text { Country }\end{array}$ & \#Deals & $\begin{array}{l}\text { Value } \\
\text { (US\$ } \\
\text { mil) }\end{array}$ & $\begin{array}{l}2014 \\
\text { Country }\end{array}$ & \#Deals & $\begin{array}{l}\text { Value } \\
\text { (US\$ } \\
\text { mil) }\end{array}$ & $\begin{array}{l}\text { 2015* } \\
\text { Country }\end{array}$ & \#Deals & $\begin{array}{l}\text { Value } \\
\text { (US\$ } \\
\text { mil) }\end{array}$ \\
\hline China & 115 & 41,308 & China & 189 & 73,617 & China & 247 & 133,277 \\
\hline Turkey & $4+$ & 12,400 & Turkey & $4+$ & 7,332 & India & 25 & 12,161 \\
\hline India & 49 & 10,689 & $\begin{array}{l}\text { Russian } \\
\text { Fed }\end{array}$ & 18 & 4,901 & Malaysia & 7 & 2,148 \\
\hline $\begin{array}{l}\text { Russian } \\
\text { Fed }\end{array}$ & 26 & 10,543 & India & 20 & 3,145 & Indonesia & 4 & 2,112 \\
\hline Brazil & 12 & 6,793 & Malaysia & 8 & 1,821 & Thailand & 4 & 1,119 \\
\hline $\begin{array}{l}\text { Total } \\
\text { non-EU } \\
2013\end{array}$ & 322 & 131,202 & $\begin{array}{l}\text { Total non } \\
\text { EU } 2014\end{array}$ & 255 & 103,512 & $\begin{array}{l}\text { Total non } \\
\text { EU } \\
2015^{*}\end{array}$ & 324 & 171,147 \\
\hline $\begin{array}{l}\text { Total } \\
\text { World } \\
2013\end{array}$ & 406 & 193,715 & $\begin{array}{l}\text { Total } \\
\text { World } \\
2014\end{array}$ & 318 & 163,171 & $\begin{array}{l}\text { Total } \\
\text { World } \\
2015^{*}\end{array}$ & 354 & 213,359 \\
\hline
\end{tabular}

*estimates as of 30/08/2015. Source: Privatisation Barometer Report 2013-2014.

China and India were the two top emerging countries by total privatisation revenues in 2015

(see Tabe 1). The five largest single deals outside the developed world in 2014 were realized

in China (see Table 2), with the recapitalization and primary share offering of CITIC Pacific

Ltd, the private placement of BOE Technology Group, the primary-share IPO of Dalian

Wanda Commercial, and finally the primary-share IPO of CGN Power and of HK Electrical

Investments Ltd.

Table 2: Top 5 Deals Developing/Emerging countries in 2010, 2011, 2013 and 2014 (data not available for 2012)

\begin{tabular}{|c|c|c|c|c|c|}
\hline Date & Company name & Nation & Sector & $\begin{array}{l}\text { Value } \\
\text { (US\$ mil) }\end{array}$ & $\begin{array}{l}\text { Method of } \\
\text { Sale }\end{array}$ \\
\hline 8/2014 & CITIC Pacific Ltd & China & Finance & 6,874 & Primary offer \\
\hline 3/2014 & $\begin{array}{l}\text { BOE Technology Group Co } \\
\text { Ltd }\end{array}$ & China & Services & 5,996 & Primary offer \\
\hline $12 / 2014$ & Dalian Wanda Commercial & China & Property & 3,700 & Primary offer \\
\hline $12 / 2014$ & CGN Power & China & Utilities & 3,639 & Primary offer \\
\hline $01 / 2014$ & $\begin{array}{l}\text { HK Electric Investments } \\
\text { Ltd }\end{array}$ & Hong Kong & Finance & 3,111 & Primary offer \\
\hline $04 / 2013$ & BB Seguridade & Brazil & Finance & 5,740 & Secondary \\
\hline
\end{tabular}




\begin{tabular}{|c|c|c|c|c|c|}
\hline & Participacoes & & & & offer \\
\hline 03/2013 & $\begin{array}{l}\text { Regional Electric } \\
\text { Distributors }\end{array}$ & Turkey & Utilities & 3,460 & Asset Sale \\
\hline 05/2013 & Bank VTB & Russian Fed & Finance & 3,272 & Primary Offer \\
\hline $02 / 2013$ & Sinopec Corp & China & Petroleum & 3,101 & Primary Offer \\
\hline $12 / 2013$ & $\begin{array}{l}\text { China Everbright Bank Co } \\
\text { Ltd }\end{array}$ & China & Finance & $2,998.75$ & Primary Offer \\
\hline 10/2011 & $\begin{array}{l}\text { Freight One (Russian } \\
\text { Railways) }\end{array}$ & $\begin{array}{l}\text { Russian } \\
\text { Federation }\end{array}$ & Transportation & 4,200 & Secondary \\
\hline 02/2011 & "Bank VTB" & $\begin{array}{l}\text { Russian } \\
\text { Federation }\end{array}$ & $\begin{array}{l}\text { Finance \& Real } \\
\text { Estate }\end{array}$ & 3,269 & Secondary \\
\hline $10 / 2011$ & Carabobo 2 Block Project & Venezuela & $\begin{array}{l}\text { Natural } \\
\text { Resources }\end{array}$ & 2,200 & Secondary \\
\hline 09/2011 & Sinohydro Group Ltd & China & Pharmaceuticals & 1,531 & Primary \\
\hline 05/2011 & $\begin{array}{l}\text { Shanghai Pharm Hldg Co } \\
\text { Ltd }\end{array}$ & China & Mining & 1,384 & Primary \\
\hline 09/2010 & Petrobras & Brazil & Oil and gas & 27,500 & Secondary \\
\hline 07/2010 & Agricultural Bank of China & China & Banking & 22,100 & IPO \\
\hline $12 / 2010$ & $\begin{array}{l}\text { Electricity and gas } \\
\text { distribution grids }\end{array}$ & Turkey & Utilities & 9,600 & Auction \\
\hline $11 / 2010$ & Petronas Chemical & Malaysia & Chemicals & 4,100 & IPO \\
\hline $10 / 2010$ & Coal India & India & Coal mining & 3,500 & IPO \\
\hline
\end{tabular}

Source: Privatisation Barometer Report 2011, 2012, 2014, 2015 
In the following section, we focus on the privatisation experience in Africa and South Asia. While the privatisation programs in Eastern Europe, China and Latin America are among the most important in terms of total proceeds (see Figure 1), a rich literature already exists (for surveys, see Estrin et al (2009) on transition economies and Estache and Trujillo (2008) on Latin America). While privatisation in Latin America and Eastern Europe culminated in the 1990s, privatisation in Africa and South Asia did not really pick up until much more recently (Roland, 2008).

\section{Privatisation patterns in Africa: a few countries only}

Privatisation programs in sub-Saharan Africa (SSA) occurred in successive waves, with some countries privatising much earlier than others (Bennell, 1997). The first group to start such programs, in the late 1970s to early 1980s, was composed of francophone West African countries (Benin, Guinea, Niger, Senegal and Togo) but their progress was limited. The second group, both Anglophone and Francophone countries (Ghana, Nigeria, Ivory Coast, Mali, Kenya, Malawi, Mozambique, Madagascar and Uganda), started privatising in the late 1980s. These programs were often influenced by pressure from the international financial institutions (Nellis, 2008) though, as noted by Bennell (1997), no significant progress was made anywhere except Nigeria until the late 1990s. The final group, the "late starters", did not start to privatise until the early to mid-1990s. Among this group, Tanzania, Burkina Faso and Zambia have shown a strong political commitment to privatisation, whereas in the other three countries (Cameroon, Ethiopia and Sierra Leone), only minimal progress was made in the 1990s.

Privatisation in the 1990s. Only a minority of SOEs in SSA were subject to privatisation over the period 1991-2001 and very little privatisation has taken place outside of South Africa, Ghana, Nigeria, Zambia and Cote d'Ivoire (Nellis, 2008). African states have 
privatised a smaller percentage (around 40\%) of their SOEs than in Latin America and the transition economies (Nellis, 2008). In addition, privatisation has generally concerned smaller manufacturing, industrial or service firms. Bennell (1997) also reports that smaller SOEs were usually targeted during the initial stages of privatisation programs in SSA because they were easier to sell. Five industries in particular were prominent in most programs: food processing, alcoholic beverages, textiles, cement and other non-metallic products, and metal products. These industries accounted for $60 \%$ of the total proceeds from the sale of manufacturing SOEs during 1988-1995 (Bennell, 1997), if we exclude the exceptional large sale of ISCOR (Iron and Steel Industrial Corporation) in South Africa.

Bennell (1997) explains that the slow progress in privatisation in the 1990s was due to a lack of political commitment compounded by strong opposition from entrenched vested interests (senior bureaucrats in ministries and SOEs themselves, as well as public sector workers concerned about their job security). For instance in Cameroon, only five of the thirty SOEs scheduled for privatisation were sold by the end of 1995. In other countries, such as Nigeria, the privatisation program started well but then stalled. Despite the fact that Nigeria's program had been one of the most successful in SSA in the 1990s, it was suspended in early 1995 in favour of a mass program of “commercialization”. In Madagascar, the privatisation program was also suspended in mid-1993 due to serious mismanagement and its unpopularity. In addition, Bennell (1997) reports that there were nationalist concerns about the possible political and economic consequences of increased foreign ownership as a result of privatisation.

However, in the late 1990s, certain political constraints lifted. First, a growing number of governments in SSA started to undertake significant economic reforms, under the aegis of the World Bank and the IMF, in which privatisation was an integral part. Reforms and privatisation were also progressively being accepted by the population. In addition, important 
political liberalization, with multi-party elections, broke with the previous statist policies, and created some room for manoeuvre to implement privatisation programs. Finally, the weak financial position of SOEs in many SSA countries and their rapid deterioration, in conjunction with the fiscal crisis of the state experienced in the 1990s, also opened the way for a sell-off of SOEs to raise government revenues and reduce expenditures.

Despite this stronger commitment, Nellis (2008) notes that there were actually few privatisation deals in Africa in the 1990s, mainly in infrastructure, and even in these the state retained significant minority stakes; around one third of the shares on average being retained. Between 1988 and 1999, the total proceeds from privatisation in SSA amounted to US\$9.8bns, with the manufacturing and services sector accounting for $36 \%$ of the total, the infrastructure $28 \%$, the energy sector $17 \%$, the primary sector $14 \%$ and the financial (and other) sector 6\% (Source: World Bank Privatisation Database).

The early to mid-2000s. There were some important privatisations in SSA between 2000 and 2008, and total proceeds increased to US\$12.654 bns (World Bank Privatisation Database). Nigeria comprised 51\% of this amount, followed by Kenya (10\%), Ghana (9\%) and South Africa (6\%). Infrastructure ${ }^{4}$ represented $73 \%$ of the total amount of the deals, followed by the manufacturing and services $\operatorname{sector}^{5}(17 \%)$, the financial sector ${ }^{6}(6 \%)$, energy ${ }^{7}$ (4\%) and the primary sector ${ }^{8}(1 \%)$ (Source: World Bank Privatisation Database).

Privatisation post 2008. Privatisation activity slowed in Africa with the economic downturn after 2008. One notable exception was Benin, with the privatisation of the cotton and the public utility sectors. The concession for the operation of the container terminal of the

\footnotetext{
${ }^{4}$ Which includes transportation, water and sewerage, telecommunications, natural gas transmission and distribution, and electricity generation, transmission, and distribution.

${ }^{5}$ Which includes agribusiness, cement, chemicals, construction, steel, hotels, tourism, airlines, maritime services and other sub-sectors that are not infrastructure or finance related.

${ }^{6}$ Which includes banks, insurance, real estate, and other financial services.

${ }^{7}$ Which includes the exploration, extraction, and refinement of hydrocarbons, oil, and natural gas.

${ }^{8}$ Which includes the extraction, refinement and sale of primary minerals and metals such as coal and iron ore.
} 
Port of Cotonou and the majority stake in the cement company were awarded to a strategic private investor in September 2009 and March 2010, respectively, and the privatisation of Benin Telecom was launched in 2009 (still ongoing) (IMF Country Report No. 10/195). Nigeria was also notable for its sale of 15 electricity generating and distribution companies in 2013, raising US\$2.50bns (Source: Privatisation Barometer 2014). In Chad, the government announced in 2015 that it was re-launching the sale of $80 \%$ of Société des Telecommunications du Tchad (Sotel-Tchad), after the previous attempt collapsed in 2010. It is important to note that the World Bank Privatisation Database does not have data on privatisation after 2008, preventing a comparison of the aggregated privatisation proceeds post-2008 to those of the earlier decades.

Privatisation in South Asia: a slow opening

Figure 3: Indian Revenues from Privatisation

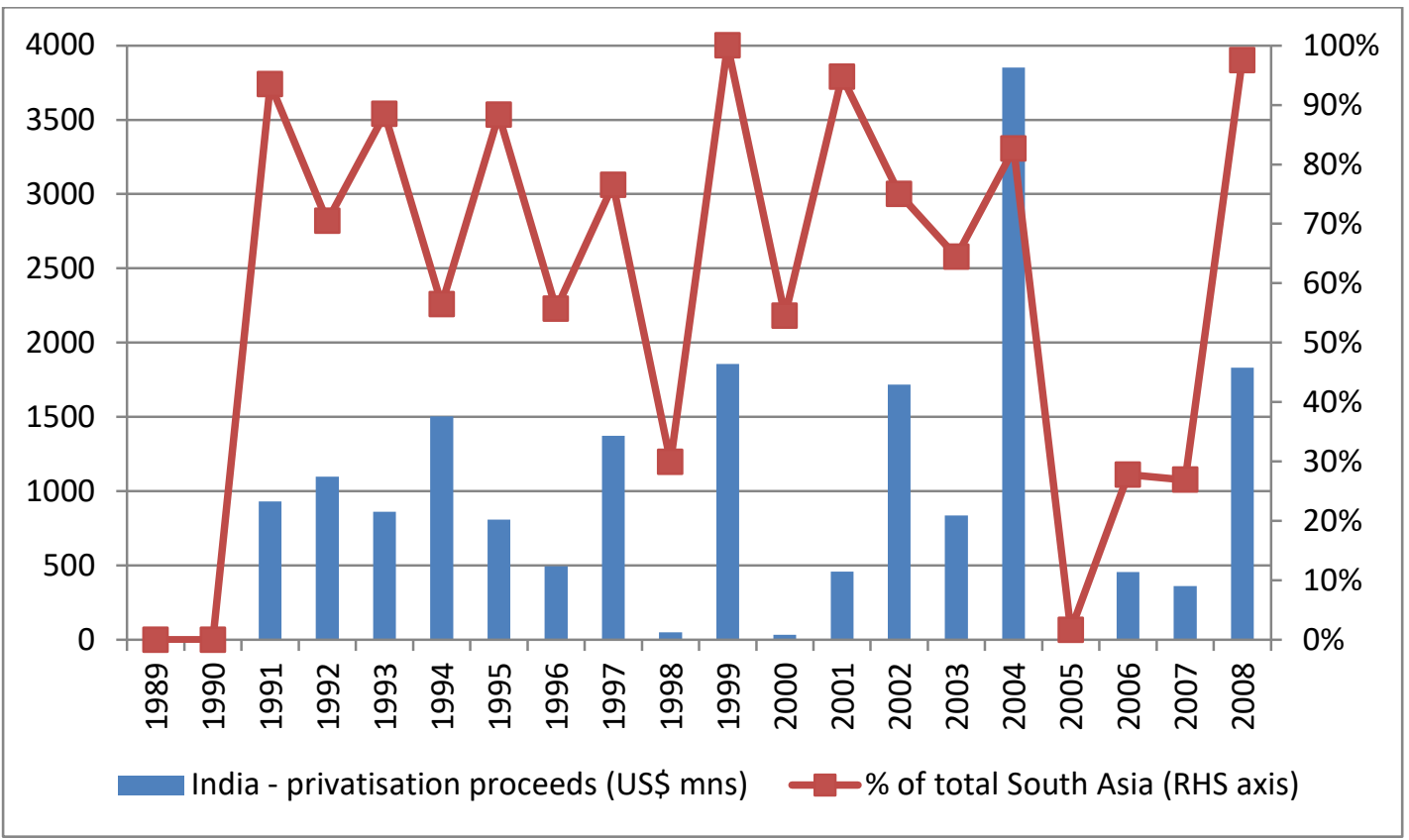

Source: World Bank Privatisation database.

Privatisations in South Asia have traditionally been rare, despite the notable inefficiency of SOEs (Gupta, 2008). The governments' reluctance to privatise can be partly explained 
historically, with the government's involvement in developing an industrial base in the postcolonial era, especially in India (Gupta, 2008). Particular sectors had been reserved exclusively for government-owned firms, such as the infrastructure sector and capital goods and raw materials industries such as steel, petroleum and heavy machinery. In addition, the government nationalized many loss-making private companies; more than half of the firms owned by the Indian federal government were loss-making in the 1990s.

Following the balance of payment crisis of 1991, the Indian government implemented a series of reforms under the Industrial Policy Resolution of 1991 to encourage private enterprise. Privatisation was initiated mainly through two approaches: partial privatisation and strategic sales. However, the former was very limited, with the government selling only minority equity stakes until 2000, and without transferring management control. Political uncertainty prevented the emergence of a coherent privatisation policy. Majority stakes sales and the transfer of management control were only conducted after the elections of 1999, and even then, until 2004 the government retained an average ownership stake of $82 \%$ in all SOEs (Gupta, 2008).

The stalled privatisation program was finally revived in 2010 with a secondary offering of shares in National Thermal Power Corporation Ltd (NTPC), which owns 20\% of India's power generation capacity (Privatisation Barometer 2009). That said, the sale of the US $\$ 1.85$ bns block of shares only reduced the government's stake by an additional 5\%, leaving $85 \%$ still under government control. In addition the process of privatisation was viewed as poor, with the secondary offering subscribed only 1.2 times, and even this after assistance from government-owned financial institutions.

In summary, between 2000 and 2008, the proceeds of privatisation in South Asia totalled US\$ 17.45 bns, the bulk being realized in India (55\%) followed by Pakistan (43\%). 
Afghanistan, Bangladesh, Nepal and Sri Lanka provided the remaining 2\% (Source: World Bank Privatisation Database). Over the 200-2008 period, the infrastructure sector represented $51 \%$ of the proceeds, followed by the energy sector (26\%), the financial sector (12\%), manufacturing and services (10\%) and the primary sector (2\%) (Source: World Bank Privatisation Database).

\section{The effects of privatisation: efficiency and firm performance}

Overall, as we report below, the studies on developing economies show that a move from state to private ownership alone does not automatically yield economic gains. A number of factors have been found to influence the success of privatisation, namely:

- Which firms are privatised; there can be a positive (or negative) selection effect.

- Whether privatisation is total or partial; evidence suggests that the former is more beneficial.

- The regulatory framework, which in turn depends on the institutional and political environment.

- The characteristics of the new owners; foreign ownership has been associated with superior business performance post-privatisation, especially relative to "insider" ownership (privatisation to managers and workers ${ }^{9}$ ).

- Effective competition. This has been found to be critical in bringing about improvements in company performance because it is associated with lower costs, lower prices and higher operating efficiency ${ }^{10}$.

\footnotetext{
${ }^{9}$ The ownership pattern resulting from privatisation often depends on the mode of privatisation chosen. Thus private sale usually leads to concentrated strategic owners while mass privatization usually generates widespread ownership at least initially. The impact of mode of privatisation on national economic performance in transition economies is explored in Bennett, Estrin and Urga (2007).

${ }^{10}$ Note however that in the utilities sector, water in particular, the technology and the nature of the product restrict the possibility of competition in the market and therefore the efficiency gains following privatisation. In this case, competition for the market (to win the contract or concession agreement) has to be organized. Given
} 
In the following sub-sections, we introduce the different estimation techniques that have been used to measure the impact of privatisation on firms' performance and then examine privatisation experiences in three sectors (banking, telecommunications and utilities) in developing countries.

\section{Measuring efficiency and firms’ performance post-privatisation}

A variety of methods have been used to measure the impact of privatisation on firms' postprivatisation performance and efficiency, measured variously by return on equity, output growth, labour productivity and changes in cost and income. But as Megginson and Sutter (2006) note, researchers face numerous methodological problems when they analyse the economic effects of privatisation. In particular, data availability and consistency, especially in developing countries, and sample selection bias -occurring, for example if the "best" firms are privatised first- represent key issues. Other problems arise when using accounting data: the determination of the correct measure of operating performance, the selection of an appropriate benchmark and statistical tests are important challenges. These issues are germane to the interpretation of the results of the studies surveyed below.

\section{Single country or single industry comparisons of costs and productivity growth of private} and government-owned firms.

An obvious way to examine the impact of government ownership on firm performance is to compare the performance of government-owned to privately owned firms. Studies in this tradition compare post-privatisation performance changes with either a comparison group of non-privatised firms or with a counterfactual. However, important methodological issues arise. First, it is difficult to determine the appropriate set of comparison firms, especially in 
developing countries where the private sector is limited. Second, selection effects and endogeneity may bias the comparison, as factors determining whether the firm is publicly or privately owned are also likely to affect performance (Gupta, Ham, Svejnar, 2008).

One of the first studies to compare SOE and private firm performance is that of Ehrlich, Gallais-Hamonno, Liu, and Lutter (1994). They used a sample of 23 comparable international airlines (18 from developed countries and 5 from developing/emerging countries) of different ownership categories over the period 1973-1983 for which they have data on cost and output for comparable goods. They find a significant association between ownership and firmspecific rates of productivity growth. Interestingly, the empirics also suggest that the benefits are based on complete privatisation of the firm, and that a partial change from state to private ownership has little effect on long-run productivity growth. Other studies have employed a similar approach examining differences in efficiency between private and government-owned firms within a specific country, such as Majumdar (1996) for Indian firms and Tian (2000) with Chinese firms. They both find that private-sector firms are more efficient.

Concerning studies using a counterfactual approach, one can cite the influential study by Galal, Jones, Tandon, and Vogelsang (1994), which was sponsored by the World Bank. They compare the actual post-privatisation performance of twelve large firms in the airlines and utilities industry in Britain, Chile, Malaysia and Mexico to a counterfactual performance. They estimate net welfare gains in eleven of the twelve cases considered, equalling on average 26 percent of the firms’ pre-divestiture sales. La Porta and Lopez-de-Silanes (1999) study privatisation in Mexico and find that privatised Mexican SOEs rapidly close a large performance gap with industry-matched private firms that had existed prior to divestment. They find that output increases by over $50 \%$ and that the privatised firms reduce employment by half, while the remaining workers see a significant pay rise. 


\section{Comparing pre-post divestment sales and income data for companies privatised by public share offering}

This set of studies examines the effects of privatisation on firm performance by comparing pre- and post-divestment data for companies privatised via public share offerings. Each firm is compared to itself (a few years earlier) using inflation-adjusted sales and income data. The first study using this methodology is by Megginson, Nash and van Randenborgh (1994) (henceforth, the MNR methodology). As Megginson and Netter (2001) note, this methodology suffers from several drawbacks, among which selection bias is probably the greatest concern, since privatisations through share sales - SIPs (Share Issue Privatisation) represent among the largest companies sold during a privatisation program. Another weakness is that the MNR methodology can only examine simple accounting variables (assets, sales, etc.), which is an issue when comparing accounting information at different points in time and in different countries. Most of the studies in this tradition also imperfectly account for macroeconomic or industry changes in the pre- and post-privatisation window (see Megginson and Netter, 2001, for a critique). Finally, the studies cannot account for the impact on privatised firms of regulatory or market-opening initiatives that are often launched in parallel with privatisation programs.

However, the MNR methodology does allow the analysis of large samples of firms from different industries, countries and time periods. In addition, while carrying the risk of selection bias, SIP samples do contain the largest and most (politically) important privatisations. Research in this tradition has focused on specific industries [banking (Verbrugge, Owens and Megginson, 2000) and tele-communications (D'Souza and Megginson, 2000)]; used data from a single country [Chile (Macquieira and Zurita, 1996)] and employed multi-industry, multinational samples. Most of these studies identify a significant improvement in company performance, post-privatisation. However, the 
significance of many of the operating and financial improvements is not robust to adjustments for changes experienced by other firms over the study period.

\section{Cross-country, multi-industry comparisons of X-efficiency and profitability ratio of} private and government-owned firms.

Another approach has been to exploit a multi-industry, multi-national cross-sectional time series to analyse the effects of government ownership on efficiency. The advantage of this method is that it captures differences that are not apparent in single-country or single-industry series. In their seminal work, Boardman and Vining (1989) use measures of X-efficiency and profitability ratios of the 500 largest non-US manufacturing and mining corporations in 1983 (“The International 500”, Fortune 1983). Privately owned firms are found to be significantly more profitable and productive than state-owned and mixed ownership enterprises but mixed enterprises are no more profitable than SOEs. Another important study is that of Frydman, Gray, Hessel and Rapaczynski (1999), which compares the performance of privatised and state firms in the transition economies of Central Europe in 1994 using a fixed effects model. To control for the possibility that better firms are selected for privatisation, they compare the pre-privatisation performance of managerially controlled firms with those controlled by other owners. They find that privatised firms perform better than the state-owned firms but that the performance improvement is related to revenue improvement rather than cost reduction in privatised firms.

\section{More recent studies using differences in differences and instrumental variable methods}

As we noted, governments sequence privatisations strategically, often leading the most profitable firms to be privatised first (Gupta, Ham and Svejnar, 2008; Dinc and Gupta, 2011). To control for selection and endogeneity biases, the latest studies have employed more 
advanced econometric techniques including differences in difference, triple differences matching methods and instrumental variable methods.

For instance, Dinc and Gupta (2011) examine the influence of political and financial factors on the decision to privatise government-owned firms in India using data from the 1990-2004 period. They find that profitable firms and firms with a lower wage bill are likely to be privatised early and that the government delays privatisation in regions where the governing party faces more competition from opposition parties. The results therefore suggest that firms' financial characteristics have a significant impact on the government's decision to privatise. This raises an identification issue for evaluating the effect of privatisation on firm performance: if more profitable firms are more likely to be privatised, we may overstate the impact of privatisation on profitability when we compare the performance of governmentowned to that of privatised firms. The authors then proceed to use political variables as instruments for the privatisation decision, adopting a two-stage least squares treatment effects regression. They find that privatisation still has a positive impact on performance in India.

Concerning share issue privatisation, a very recent work by Li, Megginson, Shen and Sun (2016) overcomes the empirical limitations of the previous SIPs studies mentioned above by employing a triple difference approach. The authors are able to separate the pure privatisation effect from the listing effect, using a database of 204 Chinese SIPs from 1999-2009 matched with otherwise comparable state-owned enterprises and privately-owned firms. The first double-difference compares the performance change of SIP firms before and after listing with the performance change of a control group of fully state-owned and unlisted SOEs to capture the combined "SIP effect" of going public and privatising. The second double-difference compares the performance change of privately-owned firms before and after their listing with the performance change of a control group of privately-owned firms that remain unlisted. This captures the "pure listing effect". They obtain the "pure privatisation effect" by taking 
the difference between these two double differences. They find there is a significant positive increase in profitability post-SIP in divested Chinese state-owned companies, even after the negative IPO listing effect is taken into account.

\section{Empirical evidence to date in developing countries}

In this section, we summarise the empirical evidence to date about the effects of privatisation on firms' performance and efficiency in developing countries, drawing on the discussion of methodology outlined above. The sectors covered include banking, telecommunications and utilities.

\section{The banking sector}

The studies reviewed by Clarke, Cull and Shirley (2005), focusing on developing countries and employing the MNR methodology or a stochastic frontier approach, find that bank performance usually improved after privatisation. For instance, Boubakri et al. (2005), applying the MNR methodology to analyse 81 bank privatisations in 22 low- and middleincome countries, find that some measures of performance improved after privatisation, but that this pattern was not common across countries; environmental factors also played a role. The study of Beck, Cull and Afeikhena (2005) in Nigeria shows that privatisation can improve bank performance, even when the macroeconomic and regulatory environment is inhospitable and the government sells the weakest banks. However, it argued that an adverse macroeconomic and regulatory environment reduces the benefits of privatisation. ${ }^{11}$ Azam, Biais and Dia (2004) also establish both theoretically and empirically the benefit of a strong, independent regulatory agency to ensure that privatised banks play an efficient role in financial development.

\footnotetext{
${ }^{11}$ Because the performance of privatised banks in the seven countries of the West African Economic and Monetary Union from 1990 to 1997 improved in the first year after privatisation but not after that.
} 
The studies surveyed by Clarke et al. (2005) also find that privatisation of banks has a greater positive effect when it is total rather than partial. This result has been found in transition countries (Bonin, Hasan and Wachtel, 2005) as well as in Brazil (Beck, Crivelli and Summerhill, 2005) and in Nigeria (Beck, Cull and Afeikhena, 2005) ${ }^{12}$. Furthermore there is evidence that privatisation boosts competition in the banking sector. For instance, Otchere (2005) examines share-issue privatisations in nine countries using the MNR methodology and finds that rival banks suffered abnormally negative returns following privatisation announcements, which suggests that shareholders expected more intense competition and lower returns.

Thus performance improves more when the government fully relinquishes control; when banks are privatised to strategic investors rather than through share issues; and when bidding is open to all, including foreign banks (Clarke et al., 2005; Megginson, 2005). A more recent paper by Clarke, Cull and Fuchs (2009) which examines the privatisation of Uganda Commercial Bank (UCB) to the South African bank Stanbic, shows that these elements of best practice also apply when the banking sector is concentrated and under-developed. The government fully relinquished control to a strategic investor in an open sales process that allowed foreign participation and the authors found that profitability improved postprivatisation with no evidence that outreach declined.

\section{The telecommunications sector}

One of the first telecom studies focused on developing countries by Wallsten (2001) used a panel of 30 African and Latin American countries from 1984-1997 with a methodology similar to MNR. Overall, the author finds that competition is significantly associated with increases in per capita access and decreases in costs. However, privatisation alone is

\footnotetext{
${ }^{12}$ Improvements in performance in Nigeria were observed in fully divested banks but not in the ones where the government retained minority shareholdings.
} 
associated with few benefits, and is negatively correlated with connection capacity. In addition, privatisation only improves performance when coupled with effective and independent regulation and increases in competition.

More recently, Gasmi, Maingard, Noumba and Recuero-Virto (2012) have examined the impact of privatisation of the fixed-line telecommunications operator on sector performance, analysing the outcomes of privatisation reforms in a 1985-2007 panel dataset on a selection of 108 countries (OECD, Asia, Africa, Latin America). They find that the impact of privatisation on sector outcomes (fixed-line deployment, cellular deployment, labour efficiency, price of fixed-line) was positive in the OECD, Central America and the Caribbean and in resource-scarce coastal Africa and Asia. However it was negative in South America and in African resource-scarce landlocked countries and no significance was identified in resource-rich African countries.

Gasmi et al. (2012) note that countries with successful privatisations have developed their infrastructure through the creation of appropriate institutional structures which have improved the effectiveness of infrastructure policies and that the coverage of networks increased thanks to the additional capital available with privatisation. In contrast, privatisation outcomes proved to be poor in South America, in African resource-scarce landlocked and African resource-rich countries, due to weak contractual design and inadequate enforcement of policies in the infrastructure sector, as well as insufficient aggregate demand. In the absence of strong state capacity, competition appeared to be a more effective instrument to foster performance than privatisation.

The extent of infrastructure privatisation also diverged across regions. While almost all OECD countries have privatised their telecommunications utilities, the rate of privatisation is only around 70\% in Latin American, Asian, and African resource-scarce coastal countries. In 
African resource-scarce landlocked and resource-rich countries, the percentage of privatised infrastructure in telecommunications is even lower, at around $40 \%$ and $30 \%$ respectively. Overall, the study by Gasmi et al. (2012) shows that there were limited privatisation effects on network expansion and that productive efficiency did not increase in all the regions postprivatisation. As such, the authors conclude that there is no unique model of reform for infrastructure sectors.

\section{The utilities sector}

Turning to water privatisation, Estache and Rossi (2002) estimate a stochastic cost frontier using 1995 data from a sample of 50 water companies in 29 Asian and Pacific countries. They find that efficiency is not significantly different in private and public companies. Kirkpatrick, Parker, and Zhang (2006) use a questionnaire survey on water utilities in Africa, covering 13 countries and 14 utilities that reported private sector involvement, and undertake data envelopment analysis and stochastic cost frontier techniques. They do not find strong evidence of performance differences between state-owned water utilities and water utilities involving some private capital. The authors consider that this result is related to the technology of water provision; the costs of organizing long-term concession agreements; and regulatory weaknesses. In particular, they argue that the nature of the product ${ }^{13}$ severely restricts the potential for competition and therefore the efficiency gains. This means rivalry under privatisation must derive from the form of competition for the market-competition to win the contract or concession agreement. But, as the authors explain, transaction costs can be high in the process of contracting for water services provision; for example the costs of organizing the bidding process, monitoring contract performance, and enforcing contract terms where failures are suspected. The importance of transparent competition for the market to achieve efficiency gains and prevent the grabbing of assets by political cronies was also

\footnotetext{
${ }^{13}$ Whereas competition is feasible in telecommunications markets, it is usually cost inefficient in the market for water services given the scale of the investment in network assets required to deliver the product.
} 
evidenced by a more recent research by Tan (2012) in the context of private participation in infrastructure (PPI) in water in Malaysia. He shows that the efficiency gains of water privatisation (measured by water loss and unit costs) were inconclusive over the period 20012008. Despite this, and the subsequent renationalization of water assets, PPI continues to be promoted -being recast in the form of management contracts- because it provides captive rents. This is also evidenced in the "cherry-picking” of segments and areas for privatisation: private sector participation is concentrated in the more lucrative water treatment segment and higher income states, leaving the less profitable segments and (more rural) areas to the public sector.

In terms of privatisation of electricity, the study of Zhang, Parker and Kirkpatrick (2008) provides an econometric assessment using panel data for 36 developing and transition countries, over the period 1985-2003. They examine the impact of these reforms on generating capacity, electricity generated, labour productivity in the generating sector and capacity utilization. They find that, overall, the gains in economic performance from privatisation and regulations are limited, while introducing competition is more effective to stimulate performance. In particular, they do not find that privatisation leads to improved labour productivity or to higher capital utilization, or to more generating capacity and higher output, except when it is coupled with the establishment of an independent regulator. The authors conclude that when competition is weak, an effective regulatory system is needed to stimulate performance, while regulation of state-owned enterprises without privatisation is ineffective.

A more recent study by Balza, Jimenez and Mercado (2013) examines the relationship between private sector participation, institutional reform, and performance of the electricity sector in 18 Latin American countries over the last four decades (1971-2010) This also finds that, regardless of the level of private participation, well-designed and stable sectoral 
institutions are essential for improving the performance of the electricity sector. In particular, privatisation is robustly associated with improvements in quality and efficiency, but not with accessibility to the service. In contrast, regulatory quality is strongly associated with better performance in terms of both quality and accessibility.

\section{Summary}

The evidence from empirical studies of privatisation in developing countries suggests that the performance of banks improved significantly after privatisation in many cases. However the gains from privatisation in the utilities sector (electricity and water), tend to be limited. Finally, concerning the telecommunications sector, the impact of privatisation on efficiency and coverage varies by region. It has been shown to be positive in Central America and in resource-scarce coastal Africa and Asia, but negative in South America and in African resource-landlocked countries. Thus, the results are context as well as sector specific. The main factors explaining this variation are regulatory quality (and behind that the quality of institutions), heterogeneity in effective competition, differences in the detail of contractual design, and in the characteristics of the new owners.

\section{Privatisation Process: Distributional impacts}

Thomas Piketty's recent book (2014), which has highlighted the importance of income distribution in the growth process, also discussed the impact of privatisation on capital accumulation. In principal, privatisation need not affect the stock of wealth in an economy, nor its distribution. State owned firms are public assets which earn a return for their owners. Provided the assets to be privatised are valued in such a way that their price represents the discounted sum of the profits to be earnt from them, then privatisation means that the state is replacing an income stream with its discounted capital value in its asset portfolio. At the same time, the private sector is purchasing an asset which generates its full value over time from its 
annual earnings. Hence privatisation does not necessarily entail a net transfer of wealth between the public and private sector.

However, the privatisation process has not always followed these principles of public finance (Estrin et al, 2009). In the extreme, as in the programs in the Czech republic or Russia, significant state assets were transferred to private hands at nominal or zero prices; in effect a transfer of wealth from the state to the private sector. More generally, state assets have frequently been deliberately undervalued. This may have been in order to sell the assets, because of the belief discussed above that they will be made more productive in private hands, or because the SOEs were loss making and the short term requirement to balance the budget overwhelmed longer-term state asset portfolio criteria. In some cases, ideological arguments have also played a role; Mrs Thatcher and several of her admirers in transition economies such as Vaclav Klaus viewed privatisation as a policy mechanism to broaden the private ownership of shares in companies (Estrin, 2002). Whatever the motivation, undervaluation of state assets leads to a net redistribution of assets from state to private hands. Piketty argues that this was an important element in relatively larger growth of private wealth in Britain than in other Western European countries between 1970 and 2010. Furthermore, it was almost certainly a major factor in what he describes as the "considerable growth of private wealth in Russia and Eastern Europe.... which led in some cases to the spectacularly rapid enrichment of certain individuals (I am thinking of the Russian oligarchs)” (2014:187).

As the quotation from Piketty makes clear, the impact on distribution of privatisation depends on how the ownership of the assets is distributed into private hands; both the pricing and to whom the SOEs are privatised. In the extreme case when assets are transferred by voucher to each citizen equally from the state to private hands at a zero or nominal price, as in the Czech Republic, there is a transfer from public to private assets equal to the value of the privatised 
firms but the impact on income distribution will be egalitarian because the process transfer to all equally. In contrast, if assets are freely transferred to a single wealthy individual, the impact will be severely to worsen the distribution of income. Typically, when assets are undervalued thay are also transferred to individuals who are already wealthy, leading to increasing wealth and income inequality.

Political factors may play a central role with corrupt elites seizing for themselves state assets, or using them to reward their cronies or political supporters. This, rather than being to improve efficiency, privatisation may be employed by the ruling group as a mechanism to redistribute wealth and resources. Acemoglu and Robinson (2010) point to the transfer of state assets into the hands of the governing elite, often associated with the deliberate continuation of monopoly power, as a mechanism of extractive political institutions; they cite the telecommunication privatisation in Mexico and the huge wealth accumulated by Carlos Slim (\$47 billion, 2016) as an example.

But negative distributional effects may also occur for reasons of perceived efficiency enhancement, for example because the state believes that particular private individuals or firms are those most likely to be able to improve company performance. This implies to a trade-off between efficiency and equity objectives in the privatisation process. Equity is supported by processes which engender dispersed ownership while it is usually argued that efficiency is driven by concentrated ownership (Estrin, 2002). The empirical evidence highlights this trade-off; $\mathrm{t}$ improvements in the performance of privatised firms have been found to depend on the subsequent ownership arrangements (Djankov and Murrell, 2002). Notably privatisation to concentrated owners, such as to foreign firms or to small groups of strategic owners yields greater improvements in performance than privatisation to the general population via share offerings, or to managers and workers (Estrin et al, 2009). 
Birdsall and Nellis (2003) place the issue of the distributional impact of privatisation more formally into an efficiency/equity framework. The effect of privatisation on income distribution between taxpayers and the new owners depends both on the initial price and on the post-sale stream of value produced. There is no unambiguous prediction about the distributional effects of privatisation, which will instead depend on initial conditions, the privatisation process and the post-privatisation political and economic environment. Any assessment of the effects should be dynamic and highly country-specific, depending on the political and economic context and its history. However, they argue that there is scope for efficiency-enhancing privatisation which also promotes equity in developing countries.

We review below the distributional impacts of privatisations through their effect on ownership, employment, prices and their fiscal effects.

A review of the distributional impacts of privatisations in the last decade

Ownership. As Megginson (2000) notes, in countries that have privatised through asset sales, the process has frequently been non-transparent and plagued by insider dealing and corruption. Thus in Russia, the "loans for shares" programs enabled well-connected financiers to obtain controlling states in the country's most valuable firms for a price well below their true value (Megginson, 2000). Moreoever, the distributional impact of voucher privatisations has also been disappointing; in Russia and the Czech Republic, the returns on the vouchers were much lower than anticipated, and very small in comparison to what a very few well-connected group of people obtained in the privatisation process (Birdsall and Nellis, 2003).

Employment. Privatisation can also affect the distribution of income through its impact on employment. As public enterprises tend to be overstaffed prior to privatisation, private ownership can lead to restructuring and consequent disproportionate laid-off of 
specific categories of worker (low-skilled for instance). The study by Chong and Lopez-deSilanes (2002) based on a survey of 308 privatised firms (covering 84 countries) over the period 1982-2000 has shown that post-sale employment was reduced in $78 \%$ of the cases likely worsening income distribution (Birdsall and Nellis, 2003).

That said, if the newly privatised firm becomes more efficient, total employment might recover after the initial restructuring phase. In addition, government-owned firms that do not privatise may also have to reduce workforce size. Research by Gupta (2011) on privatisation in India covering the 20-year period 1989-2009 shows that privatisation increases employment significantly and is not associated with a decline in employee compensation ${ }^{14}$. Moreover, she argues that an evaluation of the redistribution of wealth from the government to private owners, must also take account of the cost of subsidies to government-owned firms. However, the employment costs of privatisation will be borne by specific groups of workers, while the benefits, in terms of reduced subsidies, are distributed across taxpayers. Hence privatisation may face opposition from organized interests who benefit from maintaining government ownership.

While this is a single-country study, it has the merit of using more advanced econometric methods to control for dynamic selection bias by applying firm fixed effects and comparing privatized firms to a control group of firms that have also been selected for privatization but have not yet been sold. In addition, the share of private ownership is introduced with a lag to reduce the possibility of simultaneity between privatization and performance.

Prices and access. Privatisation can also have different impacts on income groups through prices and access to services. First, privatisation can lead to a fall in prices if it is accompanied by increased competition. In addition, if private management leads to efficiency gains, some of the savings can be passed on to consumers. However, prices may increase if

\footnotetext{
${ }^{14}$ Privatisation is also not associated with the profitability and efficiency of government-owned firms.
} 
they were previously below cost-recovery level. The distributional impact depends on how the consumption of the firms' goods and services varies by income levels. Access may increase if the privatised business is expanded through investments which could not be undertaken in public ownership. However private owners may decrease their engagement in specific, low return market segments, which may disproportionately affect the poor. Price increases are common following privatisation in network or infrastructure industries, along with increases in the quality of services. On the one hand, subsidised services tend to benefit more the relatively wealthy consumers than poorer ones; as such they may be relatively more impacted than the lower-income segment by privatisation. On the other hand, price increases following privatisation of electricity and water will increase the burden of poorer consumers, especially if it is accompanied by the end of illegal water and electricity connections (Birdsall and Nellis, 2003).

Several studies in Latin America have shown that utility privatisation has in fact led to network expansion and increased access to the service by the population, especially the rural poor [Peru (Torero and Pasco-Font, 2001); Argentina (Chisari, Estache and Romero, 1999; Delfino and Casarin, 2001; Ennis and Pinto, 2002); Bolivia (Barja and Urquiola, 2001); Mexico (Lopez-Calva and Rosellon, 2002)]. This increased network coverage has often been the consequence of market expansion enabled by private investment capital (see Clarke, Kosec and Wallsten (2004)).

When access has increased significantly without a steep rise in prices, privatisation has had positive distributional effects (Birdsall and Nellis, 2003). However, increased access has been often been accompanied by substantial price increases (Estache, Foster and Wodon, 2002). In addition, an important negative distributional impact has been through the elimination of illegal connections to electricity and water networks by lower income people. A recent paper by Hailu, Guerreiro-Osorio and Tsukada (2012) on water service privatisation in Bolivia in 
the late 1990s early 2000s, shows how tariff increases required for full cost recovery may lead to adverse privatisation outcomes; in this case the eventual renationalization of the company.

Finally, Austin, Descisciolo and Samuelsen (2016) point to the limits of privatisation in sectors with public goods characteristics. Examining the privatisation of healthcare in 99 lessdeveloped nations over the 1995-2000 period, they find that, while public health expenditures reduce tuberculosis rates in developing nations over time, this is not the case for private health expenditures.

Fiscal effects. The fiscal effects of privatisation on income distribution are indirect and come through changes in revenues and expenditures. In particular, privatisation may affect real income (net of taxes) if it reduces the tax burden differentially across households, or if it leads to increased access by the poor to government services funded by new tax flows. The study of Davis, Ossowski, Richardson, and Barnett (2000) on 18 developing and transition countries has shown that the net fiscal effects of privatisation were receipts in the order of $1 \%$ of GDP. In some countries, the main fiscal benefits of privatisation have been to eliminate subsidies. Subsidies in critical infrastructure services has often led to the rationing of under-priced services, affecting hardly poorer households which often had little or no access to these services, while the non-poor enjoyed the under-priced access. To the extent that privatisation stops these flows of subsidies, it produces indirect benefits in terms of increased retained revenues (Birdsall and Nellis, 2003), which could indirectly benefit the poor.

Table 3: Summary of distributional impacts of privatisation (spillovers)

\begin{tabular}{lll}
\hline Distributional impact & Progressive effect & Regressive effect \\
\hline Ownership & If the sale is conducted in a If the asset is under-priced and \\
& $\begin{array}{l}\text { transparent way, with a wide rewards political cronyism. If the } \\
\text { distribution of vouchers with sale is non transparent. }\end{array}$ \\
\hline
\end{tabular}




\begin{tabular}{|c|c|c|}
\hline & positive returns. & \\
\hline Employment & $\begin{array}{l}\text { If newly privatised firm become } \\
\text { more efficient and dynamic, total } \\
\text { employment might recover after the } \\
\text { initial restructuring phase }\end{array}$ & $\begin{array}{l}\text { The restructuring and consequent } \\
\text { disproportionate laid-off of specific } \\
\text { categories of worker. }\end{array}$ \\
\hline Prices & $\begin{array}{l}\text { Privatisation can lead to a fall in } \\
\text { prices if it is accompanied by } \\
\text { increased competition. In addition, } \\
\text { if private management leads to } \\
\text { efficiency gains, some of the } \\
\text { savings can be passed on to } \\
\text { consumers. }\end{array}$ & $\begin{array}{l}\text { Prices may increase if they were } \\
\text { previously below cost-recovery } \\
\text { level. }\end{array}$ \\
\hline Access & $\begin{array}{l}\text { Access may increase if the } \\
\text { privatised business is expanded } \\
\text { through investments. }\end{array}$ & $\begin{array}{l}\text { If the private owner decreases its } \\
\text { engagement in specific market } \\
\text { segments that are beneficial to the } \\
\text { poor. In addition, poorer consumers } \\
\text { can see their access reduced if } \\
\text { privatisation is accompanied by the } \\
\text { end of illegal water and electricity } \\
\text { connections. }\end{array}$ \\
\hline Fiscal & $\begin{array}{l}\text { If it leads to increased access by the } \\
\text { poor to government services funded } \\
\text { by new tax flows. }\end{array}$ & $\begin{array}{l}\text { Privatisation may affect real income } \\
\text { (net of taxes) if it reduces the tax } \\
\text { burden differentially across } \\
\text { households. Privatisation transfers } \\
\text { control rights to private interests } \\
\text { and eliminates public subsidies, } \\
\text { benefiting taxpayers but reducing } \\
\text { consumers' surplus if costs are } \\
\text { increased. }\end{array}$ \\
\hline
\end{tabular}

\section{Policy Implications}

The traditional literature, primarily concerning developed economies, argued that privatisation had largely positive effects on the economic and financial performance of the companies involved, as well as wider spillover benefits e.g. via technological diffusion from foreign ownership of former SOEs and enhanced efficiency from the privatisation of utilities and other forms of infrastructure. Moreover privatisation programs also frequently achieved additional objectives including the generation of revenues to relax state budget constraints and a broadening of share ownership amongst the population. On this basis, privatisation became an important element of reform programs in transition and then developing 
economies from the 1990s. The experience of the past twenty years leaves some of these conclusions unchanged, but leads us to a more nuanced evaluation of the effects of privatisation in the context of economic development.

In particular, though state sectors are often very large in developing economies, it has been hard to establish widespread privatisation programs in many parts of the world, partly because of political opposition. This has arisen for a variety of reasons. First, the record of privatisation as it spread to middle income and then transition economies (including China) was not always so positive as had pertained in developed economies. The lesson of the transition economy experience was that privatisation was not always a panacea: if the mode of privatisation was inappropriate or the market environment not competitive, privatisation might not enhance the performance of the firms involved (Estrin et al, 2009). Moreover, privatisation programs were associated with scandals: inappropriate valuations brought in their train the emergence of extreme inequalities of wealth. Second, in developing economies where the institutional environment, particularly with respect to regulation of monopolies, was sometimes even weaker than in transition economies, the benefits of privatisation were even less automatic, depending on the sector, and were contingent to a significant degree on the design of the privatisation program. Third, distributional issues are especially significant in developing economies, so privatisation programs had also to consider distributional impacts in ways that had been less relevant for developed economies; opposition rested on issues raised by the efficiency-equity trade-off. Finally, political economy issues are perhaps of even greater consequence for policy choices in developing economies, and privatisation programs are especially open to manipulation by extractive political institutions and elites in fragmented political environments.

This long list of concerns has meant that the spread of privatisation programs to developing countries has been limited, both geographically and with respect to sectoral reach. The 
slowdown in privatisation has no doubt been exacerbated by the global recession from 2008 and the resulting flight from risk which has particularly affected stock markets in developing economies. Moreover, the evidence about the effects of such privatisations of economic performance is more nuanced than hitherto. To be successful, a privatisation program needs to align its objectives with its methods of privatisation, taking into account the sector in which the company operates and the national, institutional and political context.

Necessary pre-conditions for successful interventions: regulatory agencies and managerial incentives

As Lopez-de-Silanes (2005) notes, good rules and contracts are key for a smooth and beneficial privatisation process. However government restructuring of SOEs prior to their sale is likely to be fraught with political difficulties because officials may try to extract private benefits. Although restructuring could increase revenues from the sale, Lopez-deSilanes (1997) suggests that restructuring policies do not lead to higher revenues. In addition, Lopez-de-Silanes (2005) notes the importance of policies to complement privatisation; in particular the need to set up an appropriate regulatory and institutional framework for the post-privatisation period.

Indeed, several papers have shown how a strong and independent regulatory can help address the negative impact of corruption on the privatisation process. Wren-Lewis (2013) uses a fixed-effects estimator on a panel of 153 electricity distribution firms across 18 countries in Latin America and the Caribbean from 1995-2007. He shows that greater corruption is associated with lower firm labour productivity but this association is reduced when an independent regulatory agency is present. However, because of broader institutional weaknesses, developing countries face many challenges in establishing a strong regulator. Gassner and Pushak (2014) have examined the impact that the UK regulatory model has had in developing and transition countries, and the extent to which they have successfully 
followed its key features; competition, independence and efficiency of service delivery through incentive-based regulation. The authors note that while regulatory agencies have spread rapidly, the success of the UK regulatory model has been only partial in middle and low-income countries. They argue that the context of developing countries, with below costrecovery tariffs and continued state-ownership, makes it more difficult to establish truly independent regulatory institutions.

Thus, developing countries face many regulatory challenges. They often start with important operational inefficiencies and insufficient revenue generation. In addition, a majority of firms in potentially regulated sectors are still publicly-owned, because they are not attractive enough for private sector investors and because governments do not want to cede control of essential services. In these circumstances, incentive regulation for efficiency savings is difficult: given the low tariffs, not enough investment can be undertaken to improve service delivery, and without private profit motives there is not a strong incentive for managers to bring about efficiency. Under-pricing and poor operational performance are serious problems: according to the 2010 Africa Infrastructure report published by the World Bank, the under-pricing of electricity costs the sector at least US\$2.2bns a year in forgone revenues ( $0.9 \%$ of GDP on average).

Recently, the concept of hybrid regulatory models has been proposed as a solution to the challenges in developing countries (Eberhard, 2007). In hybrid models, regulatory contracts and independent regulatory agencies coexist. In a context where the institutional capacity is low and/or regulatory commitment is weak, an independent regulatory agency is supplemented by contracting out or outsourcing certain regulatory functions. An illustration of this is the 20-year water and electricity concession contract in Gabon which requires using external experts to monitor the service provider's performance in achieving coverage targets. The experts are paid from dedicated funds set aside from the concessionaire's revenues and 
produce only nonbinding studies. This monitoring mechanism is aimed at strengthening the independence and competence of the ministerial department responsible for supervising the contract. Policymakers may also obtain regulatory assistance from regional regulators or from other countries through twinning arrangements. For example, the Eastern Caribbean Telecommunications Authority (ECTEL) serves the member countries of the Organisation of Eastern Caribbean States as a shared regulatory body (Tremolet, Shukla and Venton, 2004).

Taking into consideration local management and incentives is also important for a successful privatisation. Liu, Sun and Woo (2006) identify the motives of local government leaders and the constraints that they face during a privatisation process. They conclude that local governments' motivation to privatise their SOEs depends on whether the ownership transfer stimulates sufficiently the growth of local tax revenues without sacrificing bureaucrats private control benefits. In addition, Dinc and Gupta (2011) in their study of privatisation in India observed that no firm located in the home state of the minister in charge is ever privatised, which highlights the importance of local political factors in the privatisation process.

\section{What about remaining SOEs?}

To a certain extent, the recommendations about regulation and managerial incentives also apply to remaining SOEs. In fact, Bartel and Harrison (2005) argue that public-sector inefficiency is due to the softness of budget constraints and the degree of internal and external competition. This implies that efficiency gains in SOEs could be achieved by reducing or eliminating government financing for public enterprises, and/or increasing import competition.

Regarding agency-type problems, Hsieh and Song (2015) observed that one of the key reorganizations of state-owned "corporatized” firms in China was that the parent company (the controlling shareholder) of the firm incorporated as Limited Liability Corporation was to 
monitor the firm and be responsible for the compensation of the firm's senior managers. These managers were held accountable for the firm's bottom line, which reduced agency-type problems. The senior executives of the parent company, in turn, were directly appointed by the local government or by the Central Organization Department of the Communist Party.

\section{Privatisation to foreign owners}

Work on transition economies in particular established that when SOEs are privatised to foreign investors, the efficiency gains are particularly pronounced. The results on foreign ownership do seem, however to be replicated in the developing economy context. Thus Du, Harrison and Jefferson (2014) have found that foreign equity participation is associated with an improvement in productivity which is greater for SOEs than for non-SOEs in China's manufacturing sector, suggesting that foreign firms can play an important role in improving SOE performance. The benefits of privatisation via transfer to foreign firms have also been observed in the case of banking in Africa (see Clarke et al., 2005).

Part of the reason why foreign ownership improves productivity can be found in the relation between foreign ownership and corporate risk-taking. Boubakri, Cosset and Saffar (2013) found that foreign (state) ownership is positively (negatively) related to corporate risk-taking, and that this relation is stronger in countries with better institutions. To the extent that corporate risk taking is an important driver of economic growth, privatization via transfer of ownership to foreign owners should yield important economic benefits through a reorganization of prevailing incentive structures and changes in the degree of risk aversion. Jaslowitzer, Megginson and Rapp (2016) also observe that risk aversion and financial conservatism are one of the reasons why state ownership is associated with inefficiency. Using a matched panel of 624 firms they find that state ownership curtails firms' responsiveness to investment opportunities. Despite these findings, in some developing 
countries the sale of state assets to foreigners, with overtones of colonial legacies, can be a politically charged subject.

\section{Concluding comments}

Privatisation involves the transfer of productive assets from the state to private hands. Such transfers are, by their very nature, politically sensitive and subject to potential corruption and abuse. We outline below some important issues that policy makers in a developing country should consider when examining a proposed privatisation. In so doing, we assume that the primary purpose of privatisation is to enhance economic growth.

First, policy-makers need to examine and establish the preconditions for success, in terms of the business environment for competition, governance and entry. The evidence suggests that privatisation has greater benefits on firm performance in stronger business environments because the success of the process relies on effective corporate governance of the privatised entity as well as effective market competition. Key issues at the national and sectoral level include:

- Depth and liquidity of capital market (particularly important for privatisation via IPO);

- Barriers to new domestic firm entry (formal entry costs, bureaucratic costs, possibilities for incumbents to restrict entry by the use of political relationships);

- Quality of legal system concerning corporate governance for example concerning company accounting procedures, rules on minority shareholders etc.;

- Quality of business support e.g. legal firms, accounting firms, management consultants, recruitment firms;

- Openness to foreign direct investment, both via acquisitions (via privatisation) or via greenfield (to create competition), and access to foreign portfolio capital; 
- Depth and competitiveness of managerial market (pool of qualified managers);

- Strength and effectiveness of competition, and competition agency;

- Independence of anti-monopoly agency from state.

The quality and independence of the state's administrative apparatus is particularly important. Privatisation makes considerable demands on the capability of the state, both in ensuring that the process is not captured by local elites, and in managing the relationship between the government and the firm at arm's length post-privatisation, e.g. via regulation. Successful privatisation requires competent government with low levels of corruption.

Turning to the privatisation process, there is strong evidence that openness of bidding to all, including foreign firms, is a key factor of success.

Policy-makers also need to determine the appropriate privatisation methods. Related to this, the pricing of the assets to be privatized are a crucial issue with respect to the transfer of assets from public to private hands, and the likely impact on the distribution of income and wealth. The chosen methods depend in part on the preconditions noted above. Countries with poorly developed capital markets are unlikely to be able to privatise through IPOs. The main methods of privatisation, listed on the basis of the evidence of the literature in order of likely favourable impact on economic growth and development are:

- $\quad$ Sale to high quality foreign firms; ${ }^{15}$

- $\quad$ Sale on domestic capital market via IPO;

- $\quad$ Sale to domestic businesses or business groups (trade sale);

- $\quad$ Sale to existing managers and/or workers;

- Free distribution of shares to the population (mass privatisation).

\footnotetext{
${ }^{15}$ Note however that this method may suffer from a trade-off with competition objectives since foreign firms may seek local monopoly power. Such sales may be accompanied by conditions with respect to technology transfer, domestic content of inputs, employment, environment etc.
} 
There are obvious trade-offs. Free distribution ensures equality in allocation of assets around the population but is likely to lead to weak corporate governance. Sale to foreign owners, with appropriate safeguards, can raise company efficiency but may lead to job losses.

Privatisation seeks to improve company efficiency via corporate governance. However, as we have seen, there may be a number of side-effects which impact other key policy targets and these need to be considered in advance: (1) Social and economic side effects. Higher efficiency/profitability may be obtained through lower levels of employment, lower wages, reduced public service provision and higher product prices, with negative distributional and social effects. (2) Competition side effects, especially if the government is concerned to sell to foreigners and/ or to maximise revenues, then competition effects may be negative and serious. (3) Global impact. Sale of key assets such as banks or resource companies to foreign firms may restrict the range of domestic policy and hinder long term development. (4) Political side effects. Sale of assets to elites may concentrate political power and economic wealth into fewer hands. (5) Effects on distribution of income. An enhanced focus on profitability of firms may lead to increased prices of important products for poor households, as well as reduced pay, worse employment conditions and fewer job prospects. (6) Effects on fiscal balance. In principle this should be unchanged because if the asset is priced correctly the price should reflect the future expected earnings from the company. In practice, pricing may be set low, to achieve distributional targets or to support elites and friends. This would worsen the government's balance sheet. At the same time, the new owners may be more productive than the state, and hence raise activity and profits, with a positive effect on GDP and on government revenues. 


\section{References}

Acemoglu, D and Robinson, J., (2012), Why Nations Fail, New York, Random House.

Austin, K., Descisciolo, C. and Samuelsen, L. (2016) The failures of Privatization: A Comparative Investigation of Tuberculosis Rates and the Structure of Healthcare in Less-Developed Nations. World Development 78:450-460.

Azam, J.-P., Biais, B., Dia, M. (2004) Privatisation versus Regulation in Developing Economies: The case of West African Banks. Journal of African Economies 13(3):361394.

Balza, L., Jimenez, R., Mercado, J. (2013) Privatisation, institutional reform, and performance in the Latin American electricity sector. Technical Note IDB-TN-599. Inter-American Development Bank.

Barja, G., and Urquiola, M. (2001) Capitalization, regulation and the poor: access to basic services in Bolivia. WIDER Discussion Paper No. 2001/34, United Nations University.

Bartel, A. and Harrison, A. (2005) Ownership versus environment: Disentangling the sources of public-sector inefficiency. The Review of Economics and Statistics, February 2005, 87(1): 135-147.

Beck, T., Crivelli, J.M., and Summerhill, W. (2005) State bank transformation in Brazil choices and consequences, Journal of Banking \& Finance 29(8-9):2223-2257.

Beck T., Cull R. and Afeikhena J. (2005) Bank Privatisation and Performance: Empirical Evidence from Nigeria, Policy Research Working Papers. February 2005.

Bennell, Paul (1997) Privatisation in Sub-Saharan Africa: Progress and Prospects during the 1990s, World Development, 25(11):1785-1803.

Bennett, J., Estrin, S., Maw, J. and Urga, G. Methods of Privatization and Economic Growth in Transition Economies”, (2007), Economics of Transition, 15, 4, 661 -683.

Birdsall, N. and Nellis, J. (2003) Winners and Losers: Assessing the Distributional Impact of Privatisation World Development 31(10):1617-1633.

Boardman, A. and Vining, A. (1989) Ownership and Performance in Competitive Environments: A Comparison of the Performance of Private, Mixed, and State-Owned Enterprises, Journal of Law Economics 32(1):1-33.

Bonin, J.P., Hasan, I., Wachtel, P. (2005) Bank performance, efficiency and ownership in transition countries. Journal of Banking and Finance 29:31-53.

Boubakri, Narjess and Jean-Claude Cosset (1998) The Financial and Operating Performance of Newly-Privatised Firms: Evidence from Developing Countries, Journal of Finance 53:1081-110.

Boubakri N., Cosset J.-C., Fischer K., Guedhami O. (2005) Privatisation and bank performance in developing countries, Journal of Banking \& Finance 29:2015-2041.

Boubakri, N., Cosset, J.-C., Saffar, W. (2013) The role of state and foreign owners in corporate risk-taking: Evidence from privatization. Journal of Financial Economics 108:641-658. 
Chisari, O., Estache, A., and Romero, C. (1999) Winners and losers from the privatisation and regulation of utilities: lessons from a general equilibrium model of Argentina. World Bank Economic Review, 13(2), 357-378.

Chong, A. and Lopez-de-Silanes, F., (2002) Privatisation and labor force restructuring around the world, Policy Research Working Paper Series 2884, The World Bank.

Clarke, G., Kosec, K., Wallsten, S., (2004) Has private participation in water and sewerage improved coverage? Empirical evidence from Latin America, World Bank Policy Research Working Paper.

Clarke G., Cull R., Shirley M. (2005) Bank privatisation in developing countries: A summary of lessons and findings, Journal of Banking \& Finance 29:1905-1930.

Clarke, G., Cull, R., Fuchs, M. (2009) Bank Privatisation in Sub-Saharan Africa: The Case of Uganda Commercial Bank. World Development 37(9):1506-1521.

Davis, J., Ossowski, R., Richardson, T., and Barnett, S. (2000) Fiscal and macroeconomic impact of privatisation. International Monetary Fund Occasional Paper No. 194, IMF, Washington, DC.

Delfino, J. A., and Casarin, A. A. (2001) The reform of the utilities sector in Argentina. UN University WIDER Discussion Paper No. 2001/74, June.

Dinc, S., and Gupta, N. (2011) The Decision to Privatise: Finance and Politics. The Journal of Finance LXVI(1):241-269.

Du, L., Harrison, A., Jefferson, G. (2014) FDI Spillovers and Industrial Policy: The Role of Tariffs and Tax Holidays. World Development 64:366-383

Djankov, S. and Murrell, P. (2002) Enterprise Restructuring in Transition: A Qualitative Survey. Journal of Economic Literature 40 (3): 739-793.

D’Souza, J. and Megginson, W., (2000) Sources of Performance Improvement in Privatised Firms: A Clinical Study of the Global Telecommunications Industry, working paper, U. Oklahoma.

Eberhard, A. (2007) Infrastructure Regulation in Developing Countries, An exploration of hybrid and transitional models, Public Private Infrastructure Advisory Faculty (PPIAF), Washington D.C.: The World Bank.

Ehrlich, I., Gallais-Hamonno, G., Liu, Z., and Lutter, R. (1994) Productivity Growth and Firm Ownership: An Empirical Investigation, Journal of Political Economy 102:100638.

Ennis, H. M., and Pinto, S. M. (2002) Privatisation and income distribution in Argentina. Unpublished paper delivered to a seminar on Privatisation and Inequality in Latin America, Inter-American Development Bank and Universidad de las Americas, Puebla, Mexico, May.

Estache, A., Foster, V., and Wodon, Q. (2002) Accounting for poverty in infrastructure reform. World Bank Institute of Development Studies, Washington, DC. 
Estache A., and Rossi M. (2002) How Different Is the Efficiency of Public and Private Water Companies in Asia? World Bank Economic Review 2002 16(1):139-147.

Estache, A. and Trujillo, L. (2008) Privatization in Latin America: The good, the ugly and the unfair. In Roland, G. (ed.), Privatisation: successes and failures.

Estrin, S. (2002) Competition and Corporate Governance in Transition, Journal of Economic Perspectives, 16, (1), 101-124.

Estrin S., Hanousek J., Kocenda E., and Svejnar J. (2009) The Effects of Privatisation and Ownership in Transition Economies, Journal of Economic Literature, 47(3):699-728.

Frydman, R., Gray, C., Hessel, M., and Rapaczynski, A. (1999) When Does Privatisation Work? The Impact of Private Ownership on Corporate Performance in Transition Economies, Quarterly Journal of Economics 114(4):1153-91.

Galal, A., Jones, L., Tandon, P., and Vogelsang, I. (1994) Welfare Consequences of Selling Public Enterprises. Oxford: Oxford U. Press.

Gasmi F., Maingard A., Noumba P., Recuero Virto L. (2013) The Privatisation of the FixedLine Telecommunications Operator in OECD, Latin America, Asia, and Africa: One Size Does Not Fit All, World Development 45:189-208.

Gassner, K. and Pushak, N. (2014) 30 years of British utility regulation: Developing country experience and outlook, Utilities Policy 31: 44-51.

Gupta, N. (2008) Privatisation in South Asia. In Roland, G. (ed.), Privatisation: successes and failures.

Gupta, N. (2011) Selling the family silver to pay the grocer's bill? Working Paper, Indiana University https://kelley.iu.edu/nagupta/gupta_mar2011.pdf.

Gupta, N., Ham, J. C., Svejnar, J. (2008) Priorities and sequencing in privatisation: Evidence from Czech firm panel data, European Economic Review 52:183-208.

Hailu, D. and Guerreiro Osorio, R. and Tsukada, R. (2012) Privatisation and Renationalisation: What Went Wrong in Bolivia's Water Sector? World Development 40(12):2564-2577.

Hsieh, C.-T., Song, M. (2015) Grasp the Large, Let Go of the Small: The Transformation of the State Sector in China. Brookings Papers on Economic Activity, Spring 2015.

Jaslowitzer, P., Megginson, W.L., Rapp, M. S. (2016) Disentangling the effect of state ownership on investment - evidence from Europe. Working Paper.

Jomo, K.S. (2008) A critical review of the evolving privatisation debate. In Roland, G. (ed.), Privatisation: successes and failures.

Kikeri, S. and Nellis, J. (2004) An Assessment of Privatisation, The World Bank Research Observer, 19 (1): 87-118.

Kirkpatrick C., Parker D., and Zhang Y.-F. (2006) An Empirical Analysis of State and Private-Sector Provision of Water Services in Africa, The World Bank Economic Review, 20 (1):143-163. 
La Porta, R. and Lopez-de-Silanes, F. (1999) Benefits of Privatisation-Evidence from Mexico, Quarterly Journal of Economics, 114(4):1193-242.

Liu, G., Sun P., Woo, W.T. (2006) The Political Economy of Chinese-Style Privatisation: Motives and Constraints, World Development 34(12):2016-2033.

Li, B., Megginson, W. L., Shen, Z., Sun, Q. (2016) Do share issue privatisations really improve firm performance in China? Working Paper.

Lopez-Calva, L. F., and Rosellon, J. (2002). Privatisation and inequality in Mexico. Unpublished paper delivered to a seminar on Privatisation and Inequality in Latin America, Inter-American Development Bank and Universidad de las Americas, Puebla, Mexico, May.

Lopez-de-Silanes, F. (1997) Determinants of Privatisation Prices, Quarterly Journal of Economics 107(4): 965-1025.

Lopez-de-Silanes, F. (2005), “Dos and Don'ts in Privatisation: Evidence from Less Developed Countries”, The PB Newsletter, No. 2.

Macquieira, C. and Salvador Z. (1996) Privatisaciones en Chile: Eficiencia y Politicas Financieras, Estudios de Administracion 3(2) :1-36.

Majumdar, S. K. (1996) Assessing Comparative Efficiency of the State-Owned, Mixed, and Private Sectors in Indian Industry, Public Choice 96 :1-24.

Megginson, W. (2000) Privatisation, Foreign Policy 118:14-27.

Megginson, W. L. (2005). The economics of bank privatisation. Journal of Banking and Finance, 29(8-9), 1931-1980.

Megginson, W., Nash, R., and van Randenborgh, M. (1994) The Financial and Operating Performance of Newly Privatised Firms: An International Empirical Analysis, Journal of Finance 49:403-52.

Megginson, W. and Netter, J. (2001) From State to Market: A Survey of Empirical Studies on Privatisation, Journal of Economic Literature 39(2):321-389.

Megginson, W. L., and Sutter, N. (2006). Privatisation in developing countries. Corporate Governance 14:234-265.

Nellis, J. (2008) Privatisation in Africa. What has happened? What is to be done? In Roland, G. (ed.), Privatisation: successes and failures.

Otchere, I. (2005) Do privatised banks in middle- and low-income countries perform better than rival banks? An intra-industry analysis of bank privatisation, Journal of Banking \& Finance 29(s 8-9):2067-2093.

Piketty, T. (2014) Capital in the Twenty-First Century. Cambridge, MA: Belknap Press.

Privatisation Barometer (2015) Privatisation Barometer Report 2014-2015. The wave builds.

Privatisation Barometer (2014) Privatisation Barometer Report 2013-2014. Riding the wave.

Privatisation Barometer (2012) Privatisation Barometer Report 2012. Financial Crises and Declining Privatization. 
Privatisation Barometer (2011) Privatisation Barometer Report 2011. A surprisingly strong year.

Privatisation Barometer (2010) Privatisation Barometer Report 2010. Here comes another privatisation wave.

Privatisation Barometer (2009) Privatisation Barometer Report 2009. Privatising America.

Roland, G. (2008), Private and public ownership in Economic Theory. In Roland, G. (ed.), Privatisation: successes and failures.

Tan, J. (2012) The Pitfalls of Water Privatisation: Failure and Reform in Malaysia. World Development 40(12)-2552-2563.

Tian, G. (2000) State Shareholding and Corporate Performance: A Study of a Unique Chinese Data Set, working paper, London Business School.

Torero, M., and Pasco-Font, A. (2001) The social impact of privatisation and the regulation of utilities in Peru. World Institute for Development Economics Research (WIDER), Discussion Paper No. 2001/17, United Nations University.

Tremolet, S., P. Shukla, and C. Venton (2004) "Contracting Out Utility Regulatory Functions.” ERM report. World Bank, Washington D.C.

Verbrugge, J., Owens, W. and Megginson, W. (2000) State Ownership and the Financial Performance of Privatised Banks: An Empirical Analysis, Proceedings of a Policy Research Workshop at the World Bank, March 15-16, 1999. Dallas: Fed. Reserve Bank Dallas.

Wallsten, S. (2001) An Econometric Analysis of Telecom Competition, Privatisation, and Regulation in Africa and Latin America, The Journal of Industrial Economics 49:1-19.

Wren-Lewis, L. (2013) Do infrastructure reforms reduce the effect of corruption? Theory and evidence from Latin America and the Caribbean, Policy Research Working Paper Series 6559, The World Bank.

Zhang Y.-F., Parker D., Kirkpatrick C. (2008) Electricity sector reform in developing countries: an econometric assessment of the effects of privatisation, competition and regulation, Journal of Regulatory Economics 33:159-178. 